\title{
第2日F会場
}

一般演題：失語症 (1)

座長 井堀奈美

\section{II-F1-1＼cjkstart伝導失語におけるモダリティ別言語成績の示差性 一ブローカ失語及びウェルニッケ失語との比較検討} $-$

北海道医療大学大学院心理科学研究科

中村 佳美 亀井 尚

〔目的〕伝導失語は, 聴覚的理解力が正常に近く保持され る反面, 発語面に扔いて復唱・呼称障害を呈し, 錯語の音韻 論的形態及び特徴が診断指標と考えられてきた。今回, 伝導 失語の言語成績をモダリテイ別に比較検討し, 他の失語夕イ プとの示差性が見られるかを検証した。また，伝導失語の評 価に扔けるモダリテイ別言語成績の意義, 限界を考察した。

〔対象】脳血管障害を発症後 6 力月以内で, 標準失語症検 查 (SLTA) が施行された伝導失語症例 5 名（平均年齢 $40.6 \pm 21.2$ 歳, 男性 5 名, 発症からの平均経過月数 $2.2 \pm 0.8$ 月）を対象とした。比較対照群として失語の重症度が同程度 である, ブローカ失語症例 5 名及びウェルニッケ失語症例 5 名を対象に加えた。

〔方法】SLTA下位検查のうち7つのモダリティを分析対象 とし，14 個の下位検查成績を個別に検索した。なお，モダ リティ別の検查成績は, 各々 2 個の下位検查成績を足した得 点を $100 \%$ 換算して集計した。

〔結果〕伝導失語のモダリティ別言語成績の平均及び標準

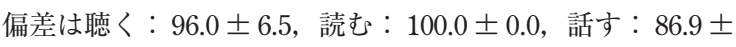
13.6, 書く : $82.0 \pm 16.4$, 復唱 : $82.7 \pm 16.7$, 音読 : $96.0 \pm$ 8.9, 書取：94.0 土 8.9 であった。モダリテイ別成績を平均値 で比較した結果，受容面と表出面とのモダリティ間で（聴 くX話す・復唱, 読むX話す・書く・復唱）統計上の有意差 
が認められた。また，復唱の成績は音読，書取の成績に比べ て, 有意差が認められた $(\mathrm{p}<0.05)$ 。ウェルニッケ失語群の モダリテイ別言語成績の平均及び標準偏差は聴く：89.0 9.6, 読む： $98.0 \pm 4.5$, 話す : $84.7 \pm 9.6$, 書く : $68.0 \pm$ 17.9 , 復唱： $77.3 \pm 19.1$, 音読： $98.0 \pm 4.5$, 書取： $88.0 \pm$ 21.7 であり, 伝導失語群との間に有意な相関が認められた $(\mathrm{r}=0.922)$ 。

〔考察〕モダリテイ別言語成績を活用するためには聴覚的 理解力と喚語・復唱能力との示差性を考慮した検査課題の開 発が求められる。

\section{II-F1-2 松と竹に助けられる「梅」〜漢字単語の音読，復 唱において特異なストラテジーを使用する伝導失語 の一症例}

医療法人禎心会病院リハビリテーション部 北海道医療大学大学院心理科学研究科 北海道医療大学大学院心理科学研究科

小松かおる

大槻美 佳 小松 雅彦

医療法人禎心会病院リハビリテーション部

$$
\text { 小橋透 澤田三津子 }
$$

同 診療部 諌山 幸弘

〔症例〕59歳, 男性, 右利き。職歴：電話受け, パソコン 入力が主な業務。主訴：ことばをうまく話せない。現病歴： 朝，寝ていた娘の所に「何か変だ」と言って起こしに来た。 救急搬送され，心原性脳梗塞の診断にて入院。

〔神経学的所見〕特に問題なし。

〔画像所見〕左中上側頭回，角回，縁上回およびそれらの 皮質下に新しい梗塞巣，右頭頂葉に古い梗塞巣を認めた。

〔神経心理学的所見〕言語：発語は失構音なし。音韻性錯 語頻出。聴理解は文レベルで中等度の障害。語音認知，若干 の低下。SLTA 呼称 $7 / 20$, 復唱は単語はほほ良好も，3 語以 上の文レベルで困難。以上より伝導失語と判断した。行為： 拙劣症 (-), 観念運動失行, 口部顔面失行を認めた。注意・ 全般的知的機能：問題なし。

〔本症例の特徵〕（1）慣用的に訓読みする漢字一文字につ いて，特異な読みの反応がみられた（「梅（うめ)」を「ショ ウチクバイのバイだよね」など)。そこで，慣用的に訓読み する漢字一文字の音読課題を実施し，音読及指定と訓読久指 定で比較した。結果は, 後者での誤りが多く $(4.2 \% / 10.4 \%)$, また所要時間も長く (188s $/ 240 s)$, 音読み傾向があった。さ らに「カタカナ語/漢字熟語」の音読課題では，後者で語の 産出時間が長く，音韻性錯語の末，目標語に達しない割合が 高かった $(19.5 \% / 29.3 \%) 。(2)$ 復唱について，本症例の内 省では，与えられた聴覚情報から直接音䫓情報に該当する絵 が浮かび，その絵に漢字をふり，漢字に仮名をふり，それを 音として表出するとのことだった。そこで, 脳内の絵の利用 有無ついて「イメージしやすい語/しにくい語」の復唱をし たところ，イメージしやすい語で語の産出時間が長いものが あり，音韻性錯語の末，目標語に達しない割合が高かった $(24.4 \% / 12.2 \%)$ 。
〔考察〕本症例は音韻表出の際，音韻操作への苦手意識の ため，意味ルートを使い，脳内の絵や漢字熟語を利用すると いう特別なストラテジーを採ったと考えられる。

\section{II-F1-3＼cjkstart急性期左視床出血に対する失語症評価}

埼玉医科大学国際医療センターリハビリテーション科

井村 純子 前島伸一郎 大沢 愛子 田澤 悠 関 泰子 三浦 千明

同 脳血管内治療科石原正一郎

同 脳卒中外科佐藤 章

同脳卒中内科棚橋 紀夫

〔目的〕視床病変では失語症を初めとする様々な高次脳機 能障害が生じることが知られている。視床病変による失語症 に関しては, 超皮質性感覚失語症に類似するとされる報告や, 視床失語という特徵的な失語症状を生じるという報告がある が，これまでのところ一定した見解が得られていない。今回 我々は，視床出血に扔ける発症初期の失語症状について質的 な検討を行ったので報告する。

〔対象と方法〕対象は，視床出血により失語症を呈した患 者 17 例（男性 10 例，女性 7 例)，年齢は $50 \sim 81(67.1 \pm 8.8)$ 歳，全例右利きであった。出血量は 5〜 58 (20.2) $\mathrm{ml}$ であっ た。方法は，発症初期に標準失語症検查（SLTA）を実施し， 失語症のタイプや SLTA総合評価尺度による失語症の重症度 と病変との関連について検討した。発症から SLTA評価まで の平均日数は， $5.8 \pm 3.5$ 日であった。

〔結果〕1）全失語 2 例, 運動性失語 4 例, 感覚性失語 1 例, 超皮質性運動失語 1 例，超皮質性感覚失語 3 例，健忘失語 6 例であり，様々なタイプの失語症が認められた。2）SLTA総 合尺度の合計得点は平均 $4.7 / 10$ 点で, 出血量が多いほど得点 が低く，失語症の重症度が高い結果であった。3）SLTA 総合 尺度では，書字の項目において 17 例中 16 例で障害を認め, そのうち 10 例は著明な得点低下を認めた。

〔結語〕出血量や病巣の進展方向と失語症のタイプや重症 度には関連が認められた。また，出血量がわずかであっても 書字の障害はほとんどの症例で合併し，「書く」能力は障害 されやすいものと思われた。

\section{II-F1-4 右半球損傷により感覚失語と談話障害を呈した一 例}

黒部市民病院リハビリテーション科

若島睦 金沢大学医薬保健研究域 能登谷晶子

黒部市民病院リハビリテーション科

吉野 修 金塚智恵子

〔はじめに〕今回，右半球損傷により失語症と談話障害， 注意障害を呈した症例を経験したので報告する。

〔症例〕 57 歳, 女性, 教育歴 12 年, 主婦。生来の右利きで, 第二子は左利き。

〔現病歴〕X年 9 月 10 日，散歩後に玄関で倒れこんだ。夫 に発見され，当院救急搬送された。頭部 CT 上，右被殼出血 
（脳室穿破）を認め，即日開頭血腫除去術が施行された。

〔神経学的所見〕左片麻痺 (BRS : 上肢 IV, 手指 III, 下肢 V)を認めた。

〔高次脳機能所見〕精神機能（発症約 1 力月目）：意識は 清明で，人格や礼節は保たれていた。RCPM は29/36点， WAIS-RはPIQ 87 であった。注意機能（発症約 $1 \sim 1$ 力月半 目）：数字抹消検査の正答率 $98.2 \%$, 文字抹消検査の正答率 $91.2 \%$ 。TMT (A) は 224 秒, TMT（B）は 574 秒と（A） (B) ともに時間を要した。SLTA検査時も不注意の傾向を示 した。MI, pacingの障害, 行為, 方向性注意, 視空間認 知・構成の障害は認められなかった。言語機能（発症約 1 〜 1カ月半目）：SLTAの聴覚的理解は単語レベルから低下， 読解は短文レベルから低下を認めた。自発話は流暢多弁。喚 語困難や語性錯語などを認め, 感覚失語の特徽を示した。ま た, 会話時には失語症以外のコミュニケーション障害を呈し ている印象を受けた。

〔考察〕本例の「まんがの説明」は左半球損傷による通常 の感覚失語とは異なり, 話の筋の展開が不十分で, 起承転結 がわかりにくい内容であった。自由会話は喚語困難や語性錯 語を認め, 咒長で多弁であり, 会話中に関係のない話題にな ったり, 前の話題に戻ったり, 会話成立が困難であった。さ らに単語の説明では細部にこだわるなどの特徴があった。本 例は右半球損傷により感覚失語と談話障害, 注意障害を呈し たと考えた。

\section{II-F1-6 右片麻㾝患者及び失語症患者の視覚と体性感覚の 異種感覚情報の統合障害〜視覚遮蔽下模倣検査によ る検討}

愛宕病院リハビリテーション科

高知大学大学院医学系研究科

沖田学

愛宕病院リハビリテーション科西善子 岡村 忠弘

〔はじめに〕運動性の失行症状である模倣障害は異種感覚 情報の統合障害として考兄られる(秋元 1976, Perfetti 2005)。 特に模倣機能では，模倣対象を自己中心的表現に変換する能 力として言語野が注目されている（乾 2000）。これを検出す るための一般的な肢体が視野に入る上肢の模倣検查では, 純 粋な異種感覚情報の統合として成り立たない。そこで, 我々 は模倣する肢体を隠した視覚遮蔽下模做検查（遮蔽下模做） を考案した。本研究ではこの検查を利用して, 右片麻疩患者 および失語症患者の異種感覚情報の統合障害の有無について 検索した。

〔対象〕対象は非麻疩側での遮蔽下模倣で手指の構成を誤 つた右側片麻疩患者 30 名（失語症 16 名）とした。また，実 験の内容を理解できなかった者や保続で誤判断した者は対象 から除外した。なお，全対象から撮影と検査の同意を得た。

〔方法〕本研究では, 非麻痺側による手指の模倣時に自己 の手指を遮蔽して見えないようする遮蔽下模倣検查と通常の 自己の手指が確認できる模倣検查（通常模倣）での検查成績 を比較した。遮蔽下模倣では, 被検者の顔と非麻疩側手指の 間に板を設置し施行した。模倣課題は 6 種類の手指構成模倣 課題とした。検查場面の映像記録から検討項目として模做の 正誤判断と達成時間を記録した。そして, 模做検査 2 条件と 失語症の有無による検討項目の成績を 2 元配置分散分析およ び多重比較検定で比較した。

〔結果〕正誤判断の比較では，2 条件の模倣検査と失語症 の有無の主効果が認められた $(\mathrm{p}<0.01)$ 。一方，これらの有 意な交互作用は認められなかった。また，それぞれの達成時 
間には有意差が認められなかった。

〔考察〕視覚遮蔽下模倣検査の課題特性により, 視覚で捉 えた検者の手指と自己の手指の形態を体性感覚によって照合 するという異種感覚情報の統合障害が明確に検出された。さ らに失語症例では異種感覚の統合能力が低下している可能性 が示唆された。 